At-Taradhi: Jurnal Studi Ekonomi

Volume X Nomor 1, Juni 2019

P-ISSN: 1979-3804, E-ISSN: 2548-9941

\title{
Peranan Adaptabilitas, Orientasi Kewirausahaan dan Inovasi dalam Meningkatkan Kinerja Usaha Mikro (Studi pada Industri Kerajinan Rotan di Kalimantan Selatan)
}

\section{Hidayatullah}

Staf Balai Pengawasan Ketenagakerjaan Daerah Wilayah IV Provinsi Kalimantan Selatan

\section{ARTICLE INFO}

Kata Kunci:

Kemampuan adaptasi; Orientasi Kewirausabaan; Inovasi; Kinerja Bisnis

\section{Cara Sitasi:}

Hidayatullah. "Peranan Adaptabilitas, Orientasi Kewirausahaan dan Inovasi dalam Meningkatkan Kinerja Usaha Mikro (Studi Pada Industri Kerajinan Rotan Di Kalimantan Selatan)" At-Taradhi: Jurnal Studi Ekonomi 10, no.1 (2019): 1-24

\begin{abstract}
The objective of this research in particular are: first, examines empirically and analysis the role of adaptability in improving the business performance directly and indirectly through entrepreneurial orientation and innovation. Second, examines empirically and analysis the role of entrepreneurial orientation in improving the business performance directly and indirectly through innovation. Population in this research is all micro business of the Rattan-craft industry in the districts of Hulu Sungai Utara and Tapin in South Kalimantan Province. Those are 244 units. Sampling method is Proportional Area Random Sampling. Total sample in this research are 152 micro businesses. Data was analyzed by SEM (Structural Equation Model) through AMOS program. The results showed that (1) adaptability plays a positive role in improving the entrepreneurial orientation and innovation, but not for business performance; adaptability has an indirect effect on business performance through innovation (2) entrepreneurial orientation plays a positive role in improving on innovation directly and business performance indirectly through innovation.
\end{abstract}

Penelitian bertujuan untuk pertama, menguji secara empiris dan menganalisis peran kemampuan beradaptasi dalam meningkatkan kinerja bisnis secara langsung dan tidak langsung melalui orientasi dan inovasi wirausaha. Kedua, menguji secara empiris dan menganalisis peran orientasi kewirausahaan dalam meningkatkan kinerja bisnis secara langsung dan tidak langsung melalui inovasi. Populasi dalam penelitian ini adalah semua usaha mikro dari industri kerajinan Rotan di kabupaten Hulu Sungai Utara dan Tapin di Provinsi Kalimantan Selatan, sebanyak 244 unit. Metode pengambilan sampel adalah Proportional Area Random Sampling. Total sampel dalam penelitian ini adalah 152 usaha mikro. Data dianalisis dengan SEM (Structural Equation Mode) melalui program AMOS. Hasil penelitian menunjukkan bahwa (1) kemampuan beradaptasi memainkan peran positif dalam meningkatkan orientasi kewirausahaan dan inovasi, tetapi tidak untuk kinerja bisnis; kemampuan beradaptasi memiliki efek tidak langsung pada kinerja bisnis melalui inovasi (2) orientasi kewirausahaan memainkan peran positif dalam meningkatkan inovasi secara langsung dan kinerja bisnis secara tidak langsung melalui inovasi. 


\section{Pendahuluan}

Usaha mikro tergolong jenis usaha marginal, yang ditandai dengan penggunaan teknologi yang relatif sederhana, tingkat modal dan akses terhadap kredit yang rendah, serta cenderung berorientasi pada pasar lokal. Berdasarkan riset World Bank, terdapat empat persoalan yang dihadapi oleh UMKM saat ini, yakni pertama, minimnya akses pembiayaan; kedua, rendahnya akses dan peluang uasaha; ketiga, terbatasnya SDM dan kelembagaan UMKM, dan keempat, regulasi dana birokrasi. ${ }^{1}$ Namun demikian sejumlah kajian di beberapa negara menunjukkan bahwa usaha mikro memiliki peranan yang cukup besar bagi pertumbuhan ekonomi, menyerap tenaga kerja melalui penciptaan lapangan pekerjaan, menyediakan barang dan jasa dengan harga murah, serta mengatasi masalah kemiskinan. ${ }^{2}$

Usaha mikro didefinisikan sebagai entitas dengan jumlah tenaga kerja kurang dari lima orang dan tingkat hasil penjualan tahunan paling banyak Rp300.000.000,00 (tiga ratus juta rupiah) dalam perekonomian Indonesia memiliki peranan penting dan strategis serta telah lama diyakini merupakan tulang punggung perekonomian daerah dan nasional. Rothwell (1994) menyatakan UKM memiliki beberapa keuntungan dengan ukuran mereka. ${ }^{3}$ Kebanyakan UKM lebih fleksibel dan memiliki hubungan yang kuat dengan para pelanggannya, sehingga memungkinkan terjadinya respon yang cepat terhadap perubahan teknis dan pasar. Usaha kecil biasanya memiliki komunikasi internal yang baik dan banyak memiliki gaya manajemen kewirausahaan yang dinamis. Selain itu, beberapa studi telah menunjukkan bahwa kemampuan teknis rata-rata orang lebih tinggi pada usaha kecil dan inovasi dalam usaha-usaha kecil ini biasanya lebih murah. ${ }^{4}$

Vossen (1998) menyatakan bahwa inovasi dalam kebanyakan usaha kecil lebih efisien dan efektif. ${ }^{5}$ Namun, banyak juga UKM yang tidak inovatif sama sekali. Banyaknya hambatan untuk inovasi dalam UKM juga telah ditekankan dalam berbagai literatur. Kurangnya sumber daya keuangan, tidak memadainya manajemen dan pemasaran, kurangnya pekerja yang terampil, kelemahan dalam informasi eksternal dan hubungan, dan kesulitan dalam menghadapi dengan peraturan pemerintah merupakan faktor yang membatasi daya saing mereka. $^{6}$

Literatur di bidang manajemen stratejik secara umum menunjukkan telah banyak studi yang meneliti faktor-faktor yang mempengaruhi kinerja usaha di sektor UKM ${ }^{7}$ dan Usaha Besar. ${ }^{8}$ Namun, masih sedikit sekali penelitian yang memfokuskan pada usaha mikro.

${ }^{1}$ Liputan6.com, “UMKM Sumbang 60 Persen ke Pertumbuhan Ekonomi Nasional," liputan6.com, July 6, 2018, https://www.liputan6.com/bisnis/read/3581067/ukm-sumbang-60-persen-ke-pertumbuhan-ekonominasional.

2Semeru, "Laporan Lapangan Keberadaan Upaya Penguatan Usaha Mikro Di Enam Kabupaten/Kota," http:// www.semeru.or.id/Report/ Field/Usabamikro2/, 2003, Buku II edition.

${ }^{3}$ R. Rothwell, Industrial Innovation: Success, Strategy, Trends (The Handbook of Industrial Innovation, 1994).

${ }^{4}$ A.C. Cooper, "R\&D Is More Efficient in Small Companies?," Harvard Business Review, 3, 42 (1964): 75-83.

${ }^{5}$ R. Vossen, "Relative Strengths and Weakness of Small Firms in Innovation," International Small Business Journal, 3, 16 (1998): 88-94.

${ }^{6}$ M.S. Freel, "Barriers to Product Innovation in Small Manufacturing Firms," International Small Business Journal, 2, 18 (2000): 60-80. Lihat juga Rothwell, Industrial Innovation: Success, Strategy, Trends.

${ }^{7}$ A. O’Donnell D Gilmore, A., Carson, D., \& Cummins, "Competitive Advantage in Small to Medium-Sized Enterprises,” Journal of Strategic Marketing, 3, 10 (2002): 205-23.

${ }^{8}$ P. Roy, "The Hewlett Packard-Compaq Computers Merger: Insight from the Resource-Based View and Dynamic Capabilities Perspective," The Journal of American Academy of Business, September 2004, 7-14. 
Kebanyakan para peneliti menyetarakan usaha mikro, kecil dan menengah ke dalam satu istilah UKM atau SME (Small Medium Enteprise). Penrose (1995) menyatakan perlu kiranya untuk melakukan pembedaan di antara UKM. UKM sangat komplek, beranekaragam dan sangat dipengaruhi banyak faktor ${ }^{9}$ yang tidak bisa ditampilkan dengan model yang statis. ${ }^{10}$

Kondisi unik dalam konteks usaha mikro meliputi struktur organisasi, budaya, gaya manajemen dan bahkan respon manajemen terhadap masalah bisnis. ${ }^{11}$ Fakta-fakta ini menunjukkan usaha mikro meminta adanya perhatian secara individual yang terpisah dari penelitian-penelitian usaha kecil dan menengah. Penelitian tentang peranan adaptabilitas, orientasi kewirausahaan, dan inovasi terhadap kinerja usaha secara parsial telah banyak ditemukan dalam berbagai literatur manajemen, tetapi studi empiris tersebut mayoritas dilakukan dengan latar belakang pada perusahaan besar di negara-negara industri. Padahal dinamika pasar pada negara-negara berkembang sangat berbeda dengan dinamika pasar pada negara-negara industri. Pada umumnya kondisi pasar pada negara-negara berkembang ditandai dengan pertumbuhan yang rendah, perubahan preferensi pembeli, dan intensitas persaingan yang tinggi. Namun sebaliknya di berapa negara berkembang kondisi pasar juga ditandai dengan pertumbuhan yang cepat, peningkatan permintaan produk, cepatnya pesaing baru masuk.

Meskipun beberapa kajian empirik telah mengemukakan adanya hubungan secara parsial antara adaptabilitas dengan inovasi dan kinerja usaha, maupun antara orientasi kewirausahaan dengan inovasi dan kinerja usaha. Namun, sampai saat ini hasil penelitian yang mengintegrasikan keempat variabel ini secara bersama-sama dalam satu model empirik masih belum jelas. Studi ini mencoba mengembangkan model penelitian empirik peranan adaptabilitas, orientasi kewirausahaan dan inovasi sebagai sumber daya tak berwujud dan sumber daya keunggulan bersaing dalam usaha meningkatkan kinerja usaha. Ide ini dikembangkan dengan pijakan integrasi teori Resources Based View (RBV). Untuk menjelaskan masalah tersebut, masalah yang diteliti dapat dirumuskan dalam pertanyaan berikut ini: Pertama, apakah adaptabilitas memiliki peranan positif dalam meningkatkan kinerja usaha secara langsung dan tidak langsung melalui orientasi kewirausahaan dan inovasi?. Kedua, apakah orientasi kewirausahaan memiliki peranan positif dalam meningkatkan inovasi dan kinerja usaha secara tidak langsung melalui inovasi?

Penelitian ini diharapkan mampu memberikan kontribusi secara teoritis berupa pengembangan ilmu pengetahuan khususnya di bidang manajemen stratejik dengan menggunakan pendekatan RBV yaitu: (1) memberikan penjelasan mengenai adanya kekurangjelasan hasil penelitian tentang hubungan antara adaptabilitas dengan kinerja usaha dan orientasi kewirausahaan dengan kinerja usaha, (2) penelitian ini dapat memberikan sumbangan pada pengembangan ilmu pengetahuan dengan menguraikan peranan adaptabilitas sebaga salah satu faktor yang dapat mempengaruhi orientasi kewirausahaan dan inovasi, sehingga dapat diperoleh kejelasan cara untuk meningkatkan orientasi kewirausahaan dan inovasi, dan (3) penelitian ini dapat memberikan sumbangan pengetahuan tentang penerapan adaptabilitas, orientasi kewirausahaan, dan inovasi pada usaha mikro dengan latar belakang negara berkembang seperti Indonesia.

'J. Loan-Clarke, Boocock, G., Smith, A. and Whittaker, J., "Investment in Management Training and Development by Small Businesses," Employee Relations, 3, 21 (1999): 296-310.

10"Human Resource Management: A Survey of Practices WithinFfamily and Non-Family Firms," Journal of European Industrial Training, 6, 25 (2001): 310-20.

${ }^{11} \mathrm{~J}$. Philipson M, "Adaptive Responses and Asset Strategies; the Experience of Rural Micro-Firms and Foot and Mouth Disease," Journal of Rural Studies 20 (2004): 227-43. 


\section{Kerangka Teoritis}

\subsection{Resource Based View (RBV)}

Teori RBV menyatakan bahwa "sumber daya organisasi yang unik dari sumber daya berwujud dan yang tak berwujud merupakan sumber keunggulan bersaing yang nyata. ${ }^{12}$ Kinerja suatu organisasi dibentuk oleh kombinasi unik dari sumber daya yang dimiliki. Sumberdaya ini termasuk aset fisik dan juga kompetensi. Fleisher \& Bensoussan (2003) menyatakan bahwa sumber keunggulan bersaing dalam sebuah perusahaan sering kali bersifat multi-faktor dengan demikian sumber ini tidak dapat hanya ditujukan pada salah satu jenis sumber daya. Hal ini mengindikasikan perlu adanya usaha untuk menghubungkan berbagai macam sumber daya yang berbeda sebagai pendorong keunggulan bersaing.

Diantara sumber daya tak berwujud yang berbeda-beda, menurut literatur pemasaran maupun manajemen stratejik terdapat dua jenis sumber daya yang dapat mempengaruhi kinerja superior. Sumberdaya ini adalah (1) Budaya organisasi dan (2) Inovasi organisasi. Hal ini sesuai dengan kategorisasi tipe sumber daya dan kapabilitas yang dikemukakan oleh Madhani (2009) yang menyatakan budaya organisasi dan inovasi merupakan dua buah sumber daya tak berwujud. Kedua jenis sumber daya tak berwujud ini merupakan sumber daya yang penting untuk mencapai keunggulan bersaing dan kinerja superior, dikarenakan sifatnya yang langka, bernilai, kompleks, sulit untuk diamati dan sangat sulit untuk ditiru. Mosakowski (1999) dan Alvarez \& dan Busenitz (2001) menyarankan agar sumber daya kewirausahaan juga dimasukkan ke dalam sumber daya tak berwujud. Sejalan dengan pendapat mereka, Runyan et al. (2006) dan Ferreira \& Azevedo, (2008) menyatakan orientasi kewirausahaan adalah sumber daya tak berwujud dan merupakan sumber daya dan kapabilitas untuk mencapai keunggulan bersaing dan dapat meningkatkan kinerja usaha kecil.

\subsection{Budaya Organisasi}

Denison (1990) mendefinisikan budaya organisasi sebagai nilai-nilai, keyakinan dan prinsipprinsip dasar yang merupakan landasan bagi sistem dan praktek-praktek manajemen serta perilaku yang meningkatkan dan menguatkan prinsip-prinsip tersebut. Sedangkan Barney (1986) mendefinisikan budaya organisasi sebagai seperangkat nilai-nilai bersama, keyakinan, asumsi dan simbol yang mengarahkan cara perusahaan menjalankan bisnisnya.

Para peneliti umumnya sepakat bahwa budaya adalah sebagai sesuatu yang sangat sulit untuk ditiru atau digandakan (Mueller, 1996), oleh karena sifatnya yang inherent tacitness, kompleksitas, dan spesifisitas (Barley, 1983; Gregory, 1983). Barney (1986) menggambarkan budaya organisasi sebagai berharga, langka dan tidak mudah ditiru secara sempurna, oleh karena itu memiliki potensi tinggi untuk menciptakan keuntungan yang berkelanjutans.

Penelitian ini mengadopsi model budaya Denison (1990) yang difokuskan pada komponen budaya adaptabilitas dengan menambahkan satu indikator fokus pemasok. Adaptabilitas dalam penelitian ini merupakan salah satu budaya organisasi, yang berfokus kepada pelanggan dan pemasok, penciptaan perubahan dan pembelajaran organisasi. Organisasi yang memiliki budaya yang adaptabel cenderung baik secara aktif dan terbuka menerima dan menterjemahkan peluang dan ancaman dari lingkungan eksternal dan merespon terhadap sinyal eksternal secara tepat (Pennington, 2003).

${ }^{12}$ J. B. Barney, "Firm Resources and Sustained Competitive Advantage," Journal of Management 17 (1991): 99_ 120. 


\subsection{Orientasi Kewirausahaan}

Runyan et. al ${ }^{13}$ dan Ferreira \& Azevedo, ${ }^{14}$ menyatakan orientasi kewirausahaan adalah sumber daya tak berwujud dan merupakan sumber daya dan kapabilitas untuk mencapai keunggulan bersaing dan dapat meningkatkan kinerja usaha kecil. RBV menganggap orientasi kewirausahaan sebagai sumber potensi dari keunggulan bersaing, oleh karena karakteristik perusahaan yang bercirikan pada kapabilitas mereka untuk secara proaktif mencari peluang dan memasuki pasar baru ${ }^{15}$. Orientasi kewirausahaan diyakini sebagai sumber utama dari keunggulan bersaing perusahaan dan kinerja keuangan. ${ }^{16}$ Para pekerja diharapkan dapat untuk menjadi lebih inovatif, proaktif, agresif dalam bersaing, dan berani mengambil resiko yang telah diperhitung, yang semuanya merupakan kapabilitas yang perlu dibangun dan ditingkatkan dari waktu ke waktu.

Lumpkin \& Dess, mendefinisikan orientasi kewirausahaan sebagai gaya pembuatan keputusan, proses dan metode yang menginformasikan kegiatan kewirausahaan perusahaan. Kewirausahaan berkaitan dengan orientasi strategi perusahaan, mencakup aspek-aspek khusus kewirausahaan dari gaya, metode dan praktik-praktik pembuatan keputusan. ${ }^{17}$ Dalam penelitiannya Ferreira \& Azevedo mengemukakan orientasi kewirausahaan sebagai dalah satu sumber daya dan kapabilitas perusahaan. ${ }^{18}$

\subsection{Inovasi}

Barney menyatakan Inovasi yang dihasilkan oleh organisasi, berpotensi untuk menjadi langka (rare), bernilai (value), tidak mudah ditiru dengan sempurna (Imperfect Imitability), sumber daya yang tidak dapat disubstitusi (Non-Subsitutability) dan memiliki probabilitas yang lebih tinggi untuk mengarah pada peningkatan hasil kinerja yang superior untuk organisasi. ${ }^{19}$

OECD (2005) menyatakan inovasi adalah implementasi yang baru atau diperbaiki secara signifikan produk (barang atau jasa), atau proses, metode pemasaran baru, atau metode organisasi baru dalam praktik bisnis, organisasi atau tempat kerja hubungan eksternal. Persyaratan minimum untuk suatu inovasi adalah bahwa produk, proses, metode pemasaran atau organisasi harus baru (atau meningkat secara signifikan) bagi perusahaan. Empat jenis inovasi dibedakan dengan dasar definisi ini: inovasi produk, inovasi proses, inovasi pemasaran dan inovasi organisasi.

\footnotetext{
${ }^{13}$ R. C. Runyan, P. Huddleston, and J. Swinney, "Entrepreneurial Orientation And Social Capital As Small Firm Strategies: A Study Of Gender Differences From A Resource-Based View," Entrepreneurship Mgt 2 (2006): 455-77.

${ }^{14} \mathrm{~J}$. Ferreira and S.G. Azevedo, "Entrepreneurial Orientation (EO) And Growth Of Firms: Key Lessons For Managers And Business Professionals,” Problems And Perspectives In Management, 6, no. 1 (2008): 81-87.

${ }^{15}$ G.T. Lumpkin and G.G. Dess, "Clarifying The Entrepreneurial Orientation Construct And Linking It To Performance," Academy of Management Review 21 (n.d.): 135-72.

${ }^{16}$ S.A. Zahra, D. O. Neubaum, and M. Huse, "Entrepreneurship In Medium-Size Companies: Exploring The Effects Of Ownership And Governance Systems," Journal of Management, 5, 26 (2000): 947-76.

${ }^{17}$ Lumpkin and Dess, "Clarifying The Entrepreneurial Orientation Construct And Linking It To Performance," 135-72.

${ }^{18}$ Ferreira and Azevedo, "Entrepreneurial Orientation (EO) And Growth Of Firms: Key Lessons For Managers And Business Professionals," 81-87.

${ }^{19}$ Barney, "Firm Resources and Sustained Competitive Advantage," 99-120.
} 
Inovasi proses dan produk adalah jenis inovasi yang paling umum diteliti. Penelitian Marcus (1988), Whittington, Pettigrew, Peck, Fenton \& Conyon (1999 berfokus hanya pada inovasi proses sedangkan penelitian Atuahene-Gima (1996), Subramanian \& Nilakanta (1996), dan Han et al. (1998) meneliti inovasi produk. Banyak dari hasil penelitian ini menunjukkan hubungan yang positif antara inovasi dan kinerja perusahaan, tetapi ada juga beberapa studi menunjukkan hubungan negatif atau bahkan tidak ada kaitan sama sekali. ${ }^{20}$

\subsection{Kinerja Usaha}

Banyak penelitian terdahulu yang berkaitan dengan kewirausahaan dan usaha kecil dalam mengukur kinerja perusahaan dengan menggunakan ukuran atau indikator yang berbedabeda. Menurut Dess \& Lumpkin (2003) ada 2 pendekatan yang digunakan untuk menilai kinerja perusahaan yaitu; pendekatan yang pertama analisis rasio keuangan (financial ratio analysis) dan pendekatan yang kedua dilihat dari perspektif pihak-pihak yang berkepentingan (stakeholder perspective). Covin \& Slevin (1990) melakukan penelitian terhadap new venture dengan mengukur kinerja perusahaan secara subjektif terhadap beberapa ukuran kinerja yang lazim dilakukan oleh peneliti seperti Bailey (1986). Bailey mengukur kinerja perusahaan dengan menggunakan ukuran subyektif yang berkaitan dengan persepsi para wirausahawan. $^{21}$

Berkaitan dengan pengukuran kinerja usaha mikro, Cooper dalam Wiklund (1999) menyatakan bahwa selama ini tidak ada konsensus dalam hal penetapan ukuran kinerja perusahaan mikro yang pasti, penelitian sebelumnya telah memfokuskan pada variabel dimana informasi mudah didapat. Para ahli menasehatkan pertumbuhan (growth) sebagai ukuran kinerja perusahaan mikro yang sangat penting. Berdasarkan uraian tersebut maka dirumuskan kerangka konseptual penelitian sebagai berikut:

Gambar 1. Kerangka konseptual penelitian

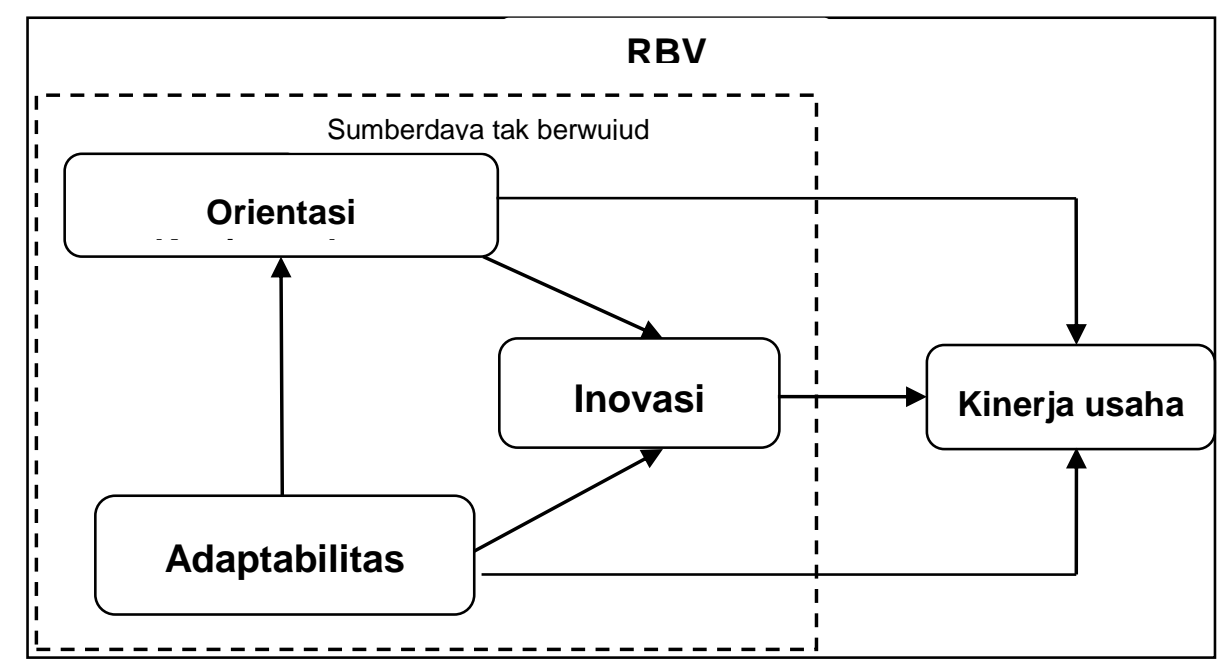

Sumber: Dikembangkan untuk penelitian ini

\footnotetext{
${ }^{20}$ Capon S. N., J.U Farley, and Hoening, "Determinants Of Financial Performance: A Meta-Analysis," Management Science 36, no. 10 (1990): 1143-59.

${ }^{21}$ J. Bailey, "Learning Styles of Successful Entrepreneurs," in Frontiers of Entrepreneurship Research (Wellesley: Babson College Press, 1986), 199-210.
} 


\section{Hipótesis Penelitian}

\subsection{Adaptabilitas dan Orientasi kewirausahaan}

Cornwall \& Perlman (1990) menyatakan bahwa budaya organisasi merupakan penentu utama kemampuan perusahaan untuk memahami, mengembangkan, atau mempertahankan aktivitas kewirausahaan. Perusahaan yang ingin mengembangkan atau mempertahankan orientasi wirausaha juga harus mengembangkan atau mempertahankan "budaya positif"salah satu yang sejalan dengan visi perusahaan, misi, dan strategi. Zahra et al. mengemukakan terdapat hubungan positif antara budaya organisasi dan kewirausahaan. ${ }^{22}$

Adaptabiltas merupakan salah satu budaya organisasi, yang berfokus kepada pelanggan, penciptaan perubahan dan pembelajaran organisasi. Organisasi yang memiliki budaya yang adaptable cenderung baik secara aktif dan terbuka menerima dan menerjemahkan peluang dan ancaman dari lingkungan eksternal dan merespon terhadap sinyal eksternal secara tepat (Pennington, 2003). Sifat budaya ini diharapkan dapat meningkatkan orientasi kewirausahaan, yang berarti pula ada peranan positif dari adaptabilitas terhadap kinerja usaha. Berdasarkan penjelasan ini, diajukan hipotesis 1.1 sebagai berikut:

Hipotesis 1.1: Semakin tinggi adaptabilitas, akan semakin tinggi orientasi kewirausahaan.

\subsection{Adaptabilitas dan Inovasi}

Budaya organisasi didefinisikan sebagai satu set keyakinan, asumsi dan simbol nilai yang kompleks dalam organisasi yang berbeda dengan yang lain. ${ }^{23}$ Organisasi harus mengembangkan lingkungan yang mendorong dan mendukung pengembangan ide untuk memfasilitasi inovasi (Tufan \& Cemil, 2007). Feldman, (1988) menyatakan budaya organisasi dianggap sebagai faktor penting dalam kinerja inovasi.

Tuominen et al. (2004) dalam penelitian mereka "How does adaptability drive firm innovativeness?, menyimpulkan bahwa hasil studi secara empirik mengindikasikan beberapa komponen adaptabilitas secara signifikan berbeda antara perusahaan yang berkinerja inovasi yang tinggi dan yang rendah, dengan demikian diharapkan adaptabilitas memiliki peranan positif dalam meningkatkan inovasi. Berdasarkan penjelasan ini, diajukan hipotesis 1.2 Sebagai berikut:

Hipotesis 1.2: Semakin tinggi adaptabilitas, akan semakin tinggi inovasi.

\subsection{Adaptabilitas dan Kinerja Usaha}

Adaptabilitas mengukur kemampuan perusahaan untuk membaca dan memindai lingkungan bisnis dan untuk menanggapi perubahan (Denison et al., 2003). Organisasi yang kuat dalam kemampuan beradaptasi biasanya mengalami pertumbuhan penjualan dan meningkatkan pangsa pasar (Denison \& Mishra, 1995). Menurut Denison et al. (2003), adaptabilitas sebagai suatu sifat budaya memiliki pengaruh utama dalam lingkungan yang berubah. Adaptabilitas memiliki tiga komponen yang secara positif berhubungan dengan kinerja usaha, yaitu creating change, customer focus dan organisational learning, yang ketiganya dalam banyak studi empiris berpengaruh positif terhadap kinerja usaha, dengan demikian dapat diharapkan adaptabilitas memiliki peranan positif terhadap kinerja usaha. Berdasarkan

\footnotetext{
${ }^{22}$ Zahra, Neubaum, and Huse, "Entrepreneurship In Medium-Size Companies: Exploring The Effects Of Ownership And Governance Systems," 947-76.

${ }^{23}$ Barney, "Firm Resources and Sustained Competitive Advantage," 99-120.
} 
penjelasan tersebut diharapkan adanya peranan positif dari adaptabilitas terhadap kinerja usaha, dengan demikian diajukan hipótesis 1.3 sebagai berikut:

Hipotesis 1.3: Semakin tinggi adaptabilitas, akan semakin tinggi kinerja usaha.

\subsection{Orientasi Kewirausahaan dan Kinerja usaha}

Pada tingkatan teoritis, orientasi kewirausahaan dikatakan memiliki efek positif pada kinerja perusahaan karena dengan postur strategis ini mempunyai penggerak pertama keunggulan dan mampu memanfaatkan peluang yang muncul, memberi mereka keunggulan kompetitif yang pada akhirnya, diterjemahkan menjadi hasil keuangan yang lebih baik. ${ }^{24}$

Pada tingkatan empiris, penelitian-penelitian terdahulu telah menunjukkan orientasi kewirausahaan adalah sumber kunci bagi perusahaan untuk mendapatkan keunggulan bersaing berkelanjutan, dan ada pengaruh positif antara orientasi kewirausahaan dan kinerja perusahaan (misalnya Lumpkin \& Dess, 1996; Zahra \& Garvis, 2000; Wiklund, 1999; Wiklund \& Shepherd, 2005; Suci 2008). Peneliti lainnya menyatakan bahwa orientasi kewirausahaan pada tingkat perusahaan mengarah pada peningkatan kinerja (Covin \& Slevin, 1991; Peters \& Waterman, 1982), kinerja yang tinggi (Bailey, 1986) serta keunggulan bersaing dan imbalan keuangan (Scholhammer, 1982). Berdasarkan penjelasan tersebut diharapkan adanya peranan positif orientasi kewirausahaan terhadap kinerja usaha, sehingga diajukan hipótesis 1.4 sebagai berikut:

Hipotesis 1.4: Semakin tinggi orientasi kewirausahaan akan semakin tinggi kinerja usaha.

\subsection{Inovasi dan Kinerja usaha}

Pengaruh inovasi terhadap kinerja organisasi telah ditemukan dalam banyak penelitian (Hurley \& Hult, 1998; Kohli \& Jaworski, 1993; Keskin, 2006; Atuahene-Gima, 2001; Damanpour, 1996), dengan hasil yang beragam, ada yang positif, ada negatif dan beberapa tidak menunjukkan hubungan sama sekali (Atuahene-Gima, 2001). Damanpour berpendapat bahwa hubungan antara inovasi dan kinerja perusahaan tergantung pada pengukuran kinerja dan karakteristik dari suatu organisasi. ${ }^{25}$

Pengaruh positif inovasi terhadap kinerja usaha telah dibuktikan dalam sejumlah studi empiris. Sebuah studi oleh Deshpande et al. (1993) antara perusahaan-perusahaan Jepang menunjukkan bahwa inovasi yang positif berkaitan dengan kinerja organisasi dalam hal relatif profitabilitas, ukuran, pangsa pasar dan tingkat pertumbuhan. Salavou (2002) meneliti di antara UKM yang beroperasi di industri makanan di Yunani dan menemukan bahwa inovasi produk adalah determinan penting kinerja usaha berdasarkan Return on Asset (ROA). Hasil penelitian Prajogo (2006) menunjukkan ada hubungan positif dari kinerja inovasi (inovasi produk dan inovasi proses) terhadap kinerja usaha, dengan demikian dapat diharapkan inovasi memiliki peranan positif terhadap kinerja usaha. Hasil penelitian Rofiaty (2010) menunjukkan inovasi memiliki pengaruh positif terhadap kinerja usaha. Berdasarkan penjelasan tersebut, diajukan hipótesis 1.5 sebagai berikut:

Hipotesis 1.5: Semakin tinggi inovasi, akan semakin tinggi kinerja usaha.

24J. Wicklund, "The Sustainability Of The Entrepreneurial Orientation-Performance Relationship," Entrepreneurship Theory and Practice 24 (1999): 37-48.

${ }^{25}$ F. Damanpour, "Organizational Complexity And Innovation: Developing And Testing Multiple Contingency Models," Management of Science, 2, 45 (1996): 693-716. 


\subsection{Adaptabilitas, Orientasi Kewirausahaan dan Kinerja Usaha}

Sebagaimana dinyatakan pada hipotesis 1.1. bahwa semakin tinggi adaptabilitas, akan semakin tinggi orientasi kewirausahaan dan hipotesis 1.4 menyatakan bahwa Semakin tinggi orientasi kewirausahaan, akan semakin tinggi kinerja usaha. Kedua hipotesis ini mengkaitkan adaptabilitas dengan orientasi kewirausahaan, dan orientasi kewirausahaan dengan kinerja usaha. Ini berarti hubungan antara adaptabilitas dan kinerja usaha dapat dihipotesiskan sebagai hubungan tak langsung. Oleh karena itu, orientasi kewirausahaan memainkan peran mediasi antara adaptabilitas dan kinerja usaha. Berdasarkan penjelasan tersebut, diajukan hipótesis 1.6 sebagai berikut:

Hipotesis 1.6: Adaptabilitas melalui mediasi orientasi kewirausahaan akan mampu meningkatkan kinerja usaha

\subsection{Adaptabilitas, Inovasi dan Kinerja Usaha}

Penelitian Denison \& Mishra (1995), Denison et al (2003), Fey \& Denison (2003), Cengiz \& Ercan (2008), Ngo \& Loi, (2008), dan Zhang et al (2009) menyimpulkan adaptabilitas memiliki pengaruh positif terhadap kinerja usaha. Selanjutnya berbagai penelitian menunjukkan bahwa inovasi memiliki peranan positif terhadap kinerja usaha. ${ }^{26}$ Ini berarti hubungan antara adaptabilitas dan kinerja usaha dihipotesiskan sebagai hubungan tak langsung. Oleh karena itu, inovasi memainkan peran mediasi antara adaptabilitas dan kinerja usaha. Secara implisit, hal ini menyatakan bahwa pengaruh kinerja usaha dari adaptabilitas dimediasi oleh inovasi. Berdasarkan penjelasan tersebut, diajukan hipotesis 1.7 sebagai berikut:

Hipotesis 1.7: Adaptabilitas melalui mediasi inovasi akan meningkatkan kinerja usaha.

\subsection{Orientasi Kewirausahaan dan Inovasi}

Slater \& Narver (1995) menunjukkan bahwa nilai-nilai kewirausahaan meningkatkan penciptaan bisnis baru dalam bisnis yang ada dan pembaruan atau kebangkitan kembali bisnis berkelanjutan yang telah menjadi stagnan atau memerlukan transformasi. Orientasi kewirausahaan telah lama dihubungkan dengan postur proaktif kompetitif, kecenderungan manajemen untuk proyek berisiko, dan perusahaan perlu terlibat dalam "bold, wideranging acts" untuk mencapai tujuan. ${ }^{27}$

Beberapa peneliti, misalnya Ireland \& Webb (2007), ${ }^{28}$ Covin \& Miles (1999) ${ }^{29}$ berpendapat bahwa kegiatan yang bersifat entrepreneurial memiliki pengaruh langsung terhadap inovasi produk, proses dan administratif. Literatur secara tradisional menganggap inovasi sebagai indikator dari kewirausahaan karena orientasi kewirausahaan dapat meningkatkan proactiveness perusahaan, kemauan untuk mengambil risiko dan berinovasi (Zahra et al., 1999), oleh karenanya orientasi kewirausahaan dan inovasi boleh jadi

\footnotetext{
${ }^{26}$ Daniel I. Prajogo, "The Relationship between Innovation and Business Performance-A Comparative Study between Manufacturing and Service Firms," Knowledge and Process Management, 3, 13 (2006): 218-25.

${ }^{27}$ Covin and Slevin, “A Conceptual Model Of Entrepreneurship As Firm Behavior,” Entrepreneurship Theory and Practice 16 (1991): 7-25.

${ }^{28}$ R. D. Ireland and J. W. Webb, “A Cross-Disciplinary Exploration of Entrepreneurship Research,” Journal of Management, 6, 33 (2007): 891-927.

${ }^{29}$ J.G. Covin and M.P. Miles, "Corporate Entrepreneurship And The Pursuit Of Competitive Advantage," Entrepreneurship Theory and Practice 23 (1999): 47-63.
} 
berhubungan. Orientasi kewirausahaan merupakan salah satu anteseden dari inovasi, ${ }^{30}$ demikian dapat diharapkan orientasi kewirausahaan memiliki peranan positif dalam meningkatkan inovasi. Berdasarkan penjelasan tersebut, diajukan hipótesis 2.1 sebagai berikut:

Hipotesis 2.1: Semakin tinggi orientasi kewirausahaan, akan semakin tinggi inovasi.

\subsection{Orientasi Kewirausahaan, Inovasi dan Kinerja usaha}

Sebagaimana dinyatakan pada hipotesis empat bahwa orientasi kewirausahaan berpengaruh terhadap kinerja usaha dan hipotesis enam menyatakan bahwa inovasi berpengaruh terhadap kinerja usaha. Kedua hipotesis ini mengkaitkan orientasi kewirausahaan dengan inovasi, dan inovasi dengan kinerja usaha. Ini berarti hubungan antara orientasi kewirausahaan dan kineja usaha dihipotesiskan sebagai hubungan tak langsung.

Penelitian Avlonitis \& Salavou (2007) dan Atuahene-Gima \& Ko (2001) menyimpulkan bahwa orientasi kewirausahaan berpengaruh positif terhadap inovasi. Selanjutnya berbagai peneliti seperti Calantone et al. (2002); Hult et al. (2004); Prajogo (2006); Keskin (2006); dan Lin \& Chen (2007) telah menyimpulkan pengaruh positif inovasi terhadap kinerja usaha. Dengan demikian, inovasi diakui memiliki pengaruh langsung terhadap kinerja perusahaan (West \& Lansiti, 2003; Brockman \& Morgan, 2003) dan dapat dianggap sebagai variabel dependen yang lebih tepat dari orientasi kewirausahaan daripada kinerja perusahaan. Penelitian ini beranggapan bahwa orientasi kewirausahaan dimediasi oleh faktor yang memiliki pengaruh langsung terhadap kinerja usaha, yaitu inovasi.

Berdasarkan penjelasan tersebut, diajukan hipotesis 2.2. sebagai berikut:

Hipotesis 2.2: Orientasi kewirausahaan melalui mediasi inovasi akan mampu meningkatkan kinerja usaha.

\section{Metode Penelitian}

\subsection{Rancangan Penelitian}

Penelitian ini merupakan penelitian eksplanatori dengan pendekatan kuantitatif yang dirancang untuk memperoleh bukti empiris, menguji dan menganalisis peranan orientasi kewirausahaan dan inovasi dalam meningkatkan kinerja usaha mikro kerajinan rotan.

\subsection{Sampel}

Unit analisis penelitian ini adalah organisasi berupa usaha mikro (Firm Leve). Yang menjadi responden adalah pemilik/pengelola usaha mikro untuk menilai orientasi kewirausahaan, inovasi dan kinerja usaha pada usaha mikro. Populasi pada penelitian ini seluruh usaha mikro kerajinan rotan dengan kriteria memiliki jumlah pekerja antara 1 - 4 orang dan memiliki hasil penjualan tahunan paling banyak Rp. 300.000.000,00 (tiga ratus juta rupiah), yang dimiliki dan dikelola sendiri oleh pemiliknya di Kabupaten HSU/Tapin di Kalimantan Selatan. Jumlah populasi dalam penelitian ini sebanyak 224, sedangkan jumlah sampel yang diteliti sebanyak 152 unit usaha. Penganbilan sampel dilakukan dengan menggunakan teknik sampel proporsional berdasarkan wilayah.

\footnotetext{
${ }^{30}$ Joaquín Alegre and Chiva Ricardo, Entrepreneurial Orientation, Innovation Firm Performance: The Importance of Organizational Learning Capability, n.d.
} 


\subsection{Pengumpulan Data}

Menurut waktu pengumpulannya jenis data yang dikumpulkan adalah data cross section. Sedangkan menurut cara memperolehnya jenis data yang digunakan dalam penelitian ini adalah: pertama, data Primer yaitu data yang diperoleh melalui wawancara langsung dengan responden, yaitu usaha mikro kerajinan rotan dengan menggunakan instrumen penelitian (kuesioner) yang telah dipersiapkan. Kedua, data sekunder yaitu data-data yang diperoleh dari Dinas Perindustrian dan Perdagangan dan Badan Pusat Statistik Provinsi Kalimantan Selatan, Kabupaten Hulu Sungai Utara dan Kabupaten Tapin dan sumber lainnya. Data sekunder digunakan untuk mendukung dan mempertajam analisis dalam studi ini

\subsection{Definisi Operasional dan Pengukuran Variabel Penelitian}

Adaptabilitas adalah penilaian pengusaha terhadap kapasitas usaha mikro kerajinan rotan dalam menyesuaikan diri dengan perubahan lingkungan eksternal. Untuk mengukur adaptabilitas dalam penelitian ini digunakan instrumen penelitian dengan mengadaptasi Denison Organisational Culture Survey (Denison \& Neale, 1996; Denison, 2006) ditambah dengan pengembangan konsep fokus pemasok. Instrumen penelitian ini menggunakan lima poin skala Likert 1 (sangat tidak setuju) - 5 (sangat setuju). Indikator yang digunakan untuk mengukur variabel adaptabilitas terdiri dari empat indikator yaitu Penciptaan Perubahan (Creating Change), Fokus pelanggan (Customer Focus), Fokus Pemasok (Supplier Focus) dan Pembelajaran Organisasi (Organisational Learning).

Orientasi kewirausahaan didefinisikan sebagai persepsi pengusaha mikro terhadap kecenderungan usaha kerajinan rotan dalam kegiatan kewirausahaan. Orientasi kewirasauahaan diukur dengan lima indikator yaitu keinovasian, keproaktifan, pengambilan resiko, keagresifan bersaing dan otonomi. . Untuk mengukur kelima indikator ini digunakan kuesioner yang digunakan oleh Li et al, (2008) yang sebelumnya mengacu pada konsep teori Miller (1983) dan Lumpkin \& Dess (1996), dengan menggunakan lima poin skala Likert 1 (sangat tidak setuju) - 5 (sangat setuju).

Inovasi dalam penelitian ini didefinisikan sebagai persepsi/penilaian pengusaha terhadap peningkatan kebaruan produk, proses dan cara pemasaran yang diimplementasikan oleh usaha mikro kerajinan rotan. Yang dimaksud dengan kebaruan adalah kebaruan bagi usaha mikro kerajinan rotan. Inovasi diukur dengan tiga indikator yaitu inovasi produk, proses dan inovasi pemasaran. Pengukuran indikator dalam penelitian ini mengacu pada OECD (2005) dan Prajogo (2006). Masing-masing item pada setiap indikator diukur dengan lima poin skala Likert 1 (sangat tidak setuju) - 5 (sangat setuju).

Kinerja usaha dalam penelitian ini didefinisikan sebagai persepsi/penilaian pengusaha mikro terhadap pertumbuhan usaha mikro kerajinan rotan selama tiga tahun (2008-2010). Kinerja usaha diukur dengan menggunakan kuesioner diadaptasi dari Lee \& Tsang (2001), Sangen (2005), dan Suci (2009), yang mengukur kinerja usaha dengan indikator-indikator seperti pertumbuhan penjualan, pertumbuhan keuntungan usaha dan pertumbuhan aset. item didasarkan pada skala semantik mulai dari "sangat lebih rendah" (1) sampai "sangat lebih tinggi" (5).

\subsection{Metode Analisis Data}

\subsubsection{Analisis Statistik Deskriptif}

Penggambaran secara deskriptif mengenai indikator-indikator dari konstruk-konstruk yang digunakan dalampenelitian ini terutama sekali adalah dengan menggunakan nilai mean dari jawaban para responden. 


\subsubsection{Analisis Statistik Inferensial}

Analisis statistik inferensial yang digunakan dalam penelitian ini adalah Structural Equation Model (SEM) yang dioperasikan dengan komputer menggunakan software AMOS untuk menguji hubungan antar konstruk dan pengujian hipotesis.

\subsection{Pengumpulan Data}

Menurut waktu pengumpulannya jenis data yang dikumpulkan adalah data cross section. Sedangkan menurut cara memperolehnya jenis data yang digunakan dalam penelitian ini terdiri dari:

(1) Data Primer yaitu data yang diperoleh melalui wawancara langsung dengan responden, yaitu usaha mikro kerajinan rotan menggunakan instrumen penelitian yang telah dipersiapkan.

(2) Data sekunder yaitu data-data yang diperoleh dari Dinas Perindustrian dan Perdagangan dan Badan Pusat Statistik Provinsi Kalimantan Selatan, Kabupaten Hulu Sungai Utara dan Kabupaten Tapin dan sumber lainnyaTeknik pengumpulan data

\subsection{Hasil try out Instrumen penelitian}

Hasil try out instrumen penelitian untuk uji validitas dan reliabilitas variabel adaptabilitas menunjukkan dari 20 item pernyataan terdapat 4 item yang memiliki nilai korelasi $(r)$ item skor total kurang dari 0,3 yaitu item FN 8 (r=0,251); FK12 (r=0,185); FK $13(\mathrm{r}=0,159)$ dan PO $18(\mathrm{r}=0,248)$ dan dikategorikan sebagai item yang tidak valid. Hal ini menyebabkan instrumen penelitian, terutama untuk mengukur indikator fokus pelanggan, fokus pemasok dan pembelajaran organisasi tidak reliabel karena memiliki nilai $\square<0,6$. Item-item yang tidak valid ini selanjutnya dikeluarkan dari instrumen penelitian yang digunakan. Pada variabel orientasi kewirausahaan, semua item yang digunakan memiliki nilai korelasi item skor total $>0,3$ dan nilai reliabilitas $>0,6$, menunjukkan semua item yang digunakan valid dan instrumen penelitian yang digunakan realiabel. Pada variabel inovasi terdapat satu item pada indikator inovasi proses, yaitu IS43 memiliki nilai 0,241 yang berarti kurang dari 0,3 sehingga item ini ini dinyatakan tidak valid dan selanjutnya dikeluarkan dari dari instrumen penelitian. Selanjutnya pada variabel kinerja usaha, semua item yang digunakan memiliki nilai korelasi item - skor total lebih dari 0,3 dan nilai reliabilitas lebih dari 0,6, menunjukkan semua item yang digunakan valid dan instrumen penelitian yang digunakan realiabel.

\section{Hasil Penelitian dan Pembahasan}

\subsection{Deskripsi Karakteristik Responden}

Hasil analisis deskriptif menunjukkan kebanyakan responden adalah laki-laki (58,6\%), sedangkan perempuan sebesar 41,4\%. Pengusaha mikro kerajinan rotan yang laki-laki di Kalimantan Selatan kebanyakan memproduksi lampit rotan dan mebel rotan. Sedangkan yang perempuannya kebanyakan membuat kerajinan anyaman rotan. Hasil penelitian menunjukkan bahwa kebanyakan responden berusia antara 34 tahun hingga 41 tahun $(39,5 \%)$ dan berusia antara 26 hingga 33 tahun $(30,3 \%)$ sedangkan yang berusia antara 18 $25(7,2 \%)$, antara $42-49(19,2 \%)$ dan yang lebih besar atau sama dengan 50 tahun hanya sebanyak 3,9\%, sehingga dapat dikatakan kebanyakan pengusaha mikro kerajinan masih dalam usia produktif.

Pendidikan terakhir dapat digunakan sebagai tolok ukur dari kemampuan atau skill seseorang. Semakin tinggi tingkat pendidikan maka semakin tinggi pula kemampuan 
ataupun skill yang dimiliki. Hasil penelitian menunjukkan bahwa 59,2\% responden memiliki tingkat pendidikan Tamat SD sederajat dan tidak tamat SD $(23,0 \%)$. Sedangkan yang memilki pendidikan. Tamat SLTP $(11,2 \%)$, Tamat SLTA $(5,9 \%)$ dan lainnya $(0,7 \%)$. Dengan demikian dapat disimpulkan sebagian besar pengusaha mikro kerajinan rotan di Kalimantan Selatan masih tergolong rendah. Dilihat dari segi pengalaman dalam berusaha di bidang industri kerajinan rotan dari para responden ternyata kebanyakan (39,5\%) responden memiliki pengalaman kerja antara lima hingga sepuluh tahun, diikuti oleh $36,2 \%$ responden yang memiliki pengalaman kerja selama lebih dari 16 tahun. Dengan demikian dapat disimpulkan sebagian besar pengusaha mikro kerajinan rotan di Kalimantan Selatan memiliki pengalaman berusaha yang tergolong tinggi.

Berdasarkan jumlah pekerja yang membantu di dalam usaha mereka, hasil penelitian menunjukkan bahwa kebanyakan responden memiliki pekerja dua orang $(61,2 \%)$. Dengan demikian dapat disimpulkan sebagian besar pengusaha mikro kerajinan rotan di Kalimantan Selatan memiliki jumlah tenaga kerja yang tergolong rendah. Jumlah pekerja yang rendah ini terutama sekali disebabkan oleh semakin menurunnya permintaan produk kerajinan rotan dari tahun ke tahun sehingga sebagian pekerja memilih bekerja di luar usaha kerajinan rotan misalnya sebagai buruh atau ojek. Selanjutnya Berdasarkan hasil penjualan tahunan rata-rata, diketahui sebagian besar usaha mikro kerajinan rotan $(53,3 \%)$ memiliki hasil penjualan tahunan kurang dari Rp. 75.000.000, diikuti oleh 34,2\% responden yang memiliki hasil penjualan tahunan antara Rp. 75.000.000 - Rp. 149.999.000. Sedangkan yang memiliki hasil penjualan tahunan antara Rp. 150.000.000 sampai Rp. 300.000 .000 hanya sebanyak 12,5\%. Dengan demikian dapat disimpulkan sebagian besar pengusaha mikro kerajinan rotan di Kalimantan Selatan memiliki tingkat penjualan tahunan yang tergolong rendah.

\subsection{Hasil Uji Validitas dan Reliabilitas Instrumen Penelitian}

Hasil analisis CFAmenunjukkan seluruh item pada variabel Adaptabilitas ,Orientasi Kewirausahaan, Inovasi dan Kinerja usaha memiliki nilai Standardized loading factor $>0,40$ dengan demikian tidak ada item yang harus dikeluarkan dari analisis. Selain itu masingmasing indiator pada setiap variabel yang diteliti telah kriteria $A V E>0,50$ menunjukkan adanya konvergen yang baik, serta mempunyai reliabilitas yang baik, jauh di atas angka $\begin{array}{llll}\text { patokan yang direkomendasikan } & \text { sebesar }\end{array}$

\subsection{Analisis Deskriptif Variabel}

Secara keseluruhan nilai mean dan interpretasi untuk variable-variabel yang diteliti berdasarkan hasil analisis deskriptif diperlihatkan pada tabel 1.

Tabel 1. Nilai mean dan interpretasi variabel-variabel penelitian

\begin{tabular}{lcl}
\hline \multicolumn{1}{c}{ Variabel } & Nilai mean & Interpretasi \\
\hline Adaptabilitas & 2,77 & Rendah \\
\hline Orientasi kewirausahaan & 2,85 & Rendah \\
\hline Inovasi & 2,77 & Rendah \\
\hline Kinerja usaha & 2,52 & Rendah \\
\hline
\end{tabular}




\subsection{Evaluasi Asumsi SEM}

\subsubsection{Ukuran sampel}

Berdasarkan ukuran sampel minimal yakni 100 sampai 200, dapat dinyatakan bahwa dengan menggunakan 152 responden dalam penelitian ini, asumsi untuk ukuran sampel telah terpenuhi.

\subsubsection{Evaluasi Normalitas Data}

Berdasarkan hasil analisis diketahui semua variabel memiliki nilai kritis di bawah 1,96. dan normalitas multivariat juga menunjukkan nilai kritis di bawah 1,96 maka dapat dikatakan bahwa data pada kategori normal.

\subsubsection{Evaluasi Outliers}

Hasil pengujian univariate dan multivariate outliers dalam studi ini mengindikasikan tidak terjadi univariate maupun multivariate outliers untuk semua variabel yang diobservasi.

\subsubsection{Evaluasi Singularitas}

Dari hasil pengolahan data, nilai determinan matriks kovarians sampel adalah 0,401 yang berada di atas angka nol yang memberikan indikasi bahwa tidak ada singularitas. Di samping itu, warning adanya singularitas juga tidak ditunjukkan oleh program, sehingga asumsi singularitas telah terpenuhi.

\subsubsection{Uji Kelayakan Model Keseluruhan}

Hasil uji fit model memperlihatkan ukuran goodness of fit yang menunjukkan kondisi yang fit hal ini disebabkan oleh angka Chi-square sebesar 45,371yang berarti lebih kecil dari cut-off value yang ditetapkan $(56,94)$ dengan nilai probabilitas 0,295 atau diatas 0,05 , nilai ini menunjukkan tidak adanya perbedaan antara matriks kovarian sampel dengan matriks kovarian populasi yang diestimasi. Ukuran goodness of fit lain juga menunjukkan pada kondisi yang baik yaitu TLI $(0,986>0,95)$; CFI $(0,990>0,95)$; CMIN/DF $(1,107<2,0)$; RMSEA $(0,027<0,08)$; GFI $(0,946>0,9)$ dan AGFI $(0,931>0,9)$ memenuhi kriteria goodness of fit.

\subsection{Pengujian Hipotesis}

Berdasarkan hasil analisis CFA dengan program AMOS 7,0 diperoleh nilai estimasi baku dan probabilitas pengaruh langsung, tidak langsung dan pengaruh total variabel penelitian sebagaimana diperlihatkan pada Tabel 2.

Tabel 2. Hasil pengujian pengaruh langsung, tidak langsung dan total variabel penelitian

\begin{tabular}{lclcccccc}
\hline & Variabel & \multicolumn{3}{c}{ Pengaruh } & Prob. & Ket. & $\begin{array}{c}\text { Hasil } \\
\text { pengujian }\end{array}$ \\
\hline Independen & Mediasi & Dependen & Langsung & $\begin{array}{c}\text { Tidak } \\
\text { langsung }\end{array}$ & Total & & & \\
\hline Adaptabilitas & - & $\begin{array}{l}\text { Orientasi } \\
\text { kewirausa- } \\
\text { haan }\end{array}$ & .541 & - & 0,541 & 0,000 & Sig. & Diterima \\
\hline Adaptabilitas & - & Inovasi & .267 & - & 0,588 & 0,045 & Sig. & Diterima \\
\hline Adaptabilitas & - & $\begin{array}{l}\text { Kinerja } \\
\text { usaha }\end{array}$ & .101 & - & 0,318 & 0,523 & Sig. & Ditolak \\
\hline $\begin{array}{l}\text { Orientasi } \\
\text { Kewirausahaan }\end{array}$ & - & $\begin{array}{l}\text { Kinerja } \\
\text { usaha }\end{array}$ & -.111 & - & 0,169 & 0,576 & $\begin{array}{c}\text { Non } \\
\text { Sig }\end{array}$ & Ditolak \\
\hline Inovasi & - & $\begin{array}{l}\text { Kinerja } \\
\text { usaha }\end{array}$ & .472 & - & 0,472 & 0,047 & Sig. & Diterima \\
\hline Adaptabilitas & $\begin{array}{l}\text { Orientasi } \\
\text { Kewirausa }\end{array}$ & $\begin{array}{l}\text { Kinerja } \\
\text { usaha }\end{array}$ & - & 0,217 & - & & - & Ditolak
\end{tabular}




\begin{tabular}{lclccccc}
\multicolumn{9}{c}{-haan } & & & & & \\
\hline Adaptabiltas & Inovasi & $\begin{array}{l}\text { Kinerja } \\
\text { usaha }\end{array}$ & - & 0,126 & - & Diterima \\
\hline $\begin{array}{l}\text { Orientasi } \\
\text { Kewirausahaan }\end{array}$ & - & Inovasi & .593 & - & 0,593 & 0,000 & Sig. \\
\hline $\begin{array}{l}\text { Orientasi } \\
\text { Kewirausahaan }\end{array}$ & Inovasi & $\begin{array}{l}\text { Kinerja } \\
\text { usaha }\end{array}$ & - & 0,280 & - & & Diterima \\
\hline
\end{tabular}

\subsection{Hasil pengujian Hipotesis}

\subsubsection{Pengujian Hipotesis 1.1}

Hasil pengujian statistik terhadap hipotesis ini menunjukkan adaptabilitas memiliki pengaruh langsung, positif dan sangat signifikan terhadap orientasi kewirausahaan dengan nilai estimasi baku (standardized estimate) sebesar 0,541 dan nilai probabilitas tingkat kesalahan $<0,001$. Dengan menggunakan tingkat signifikansi alpha 0,05 maka $H_{1.1}$ yang menyatakan "semakin kuat adaptabilitas, akan semakin tinggi orientasi kewirausahaan" dapat diterima.

\subsubsection{Pengujian Hipotesis 1.2.}

Hasil pengujian statistik terhadap hipotesis ini menunjukkan adaptabilitas memiliki pengaruh langsung, positif dan sangat signifikan terhadap inovasi dengan nilai estimasi baku sebesar 0,267 dan nilai probabilitas tingkat kesalahan 0,045. Dengan menggunakan tingkat signifikansi alpha 0,05 maka $\mathrm{H}_{1.2}$. yang menyatakan "semakin kuat adaptabilitas, akan semakin tinggi inovasi" dapat diterima.

\subsubsection{Pengujian Hipotesis 1.3.}

Hasil pengujian statistik terhadap hipotesis ini menunjukkan adaptabilitas tidak memiliki pengaruh yang signifikan terhadap kinerja usaha dengan nilai estimasi baku sebesar 0,101 dan nilai probabilitas tingkat kesalahan 0,523. Dengan menggunakan tingkat signifikansi alpha 0,05 maka hipotesis yang diajukan tidak terbukti. Ini berarti $\mathrm{H}_{1.3 .}$ yang menyatakan "semakin tinggi adaptabilitas, akan semakin tinggi kinerja usaha" ditolak.

\subsubsection{Pengujian Hipotesis 1.4.}

Hasil pengujian statistik terhadap hipotesis ini menunjukkan orientasi kewirausahaan tidak memiliki pengaruh langsung yang signifikan terhadap kinerja usaha dengan nilai estimasi baku sebesar -0,111 dan nilai probabilitas tingkat kesalahan 0,576. Dengan menggunakan tingkat signifikansi alpha 0,05 maka hipotesis yang diajukan tidak terbukti. Ini berarti $\mathrm{H}_{1.4}$ yang menyatakan "semakin tinggi orientasi kewirausahaan, akan semakin tinggi kinerja usaha" ditolak.

\subsubsection{Pengujian Hipotesis 1.5.}

Hasil pengujian statistik terhadap hipotesis ini menunjukkan inovasi memiliki pengaruh langsung yang positif, dan signifikan terhadap kinerja usaha dengan nilai estimasi baku sebesar 0,471 dan nilai probabilitas tingkat kesalahan $<0,047$. Dengan menggunakan tingkat signifikansi alpha 0,05 maka hipotesis yang diajukan terbukti. Ini berarti bahwa $\mathrm{H}_{1.5}$ yang menyatakan "semakin tinggi inovasi, semakin tinggi kinerja usaha" dapat diterima.

\subsubsection{Pengujian Hipotesis 1.6.}

Hasil pengujian $\mathrm{H}_{1.1}$. menunjukkan bahwa adaptabilitas memiliki pengaruh positip dan sangat signifikan terhadap orientasi kewirausahaan dengan nilai estimasi baku sebesar 0,541 dan nilai probabilitas tingkat kesalahan $<0,001$. Sebaliknya pada pengujian $H_{1.4}$ menemukan bahwa orientasi kewirausahaan tidak memiliki pengaruh yang signifikan 
terhadap kinerja usaha dengan nilai estimasi baku sebesar -0,111 dan nilai probabilitas tingkat kesalahan 0,576. Hal ini menunjukkan bahwa orientasi kewirausahaan tidak berperan sebagai variabel mediasi dalam hubungan antara adaptabilitas dan kinerja usaha. Hasil ini memberi makna bahwa semakin tinggi adaptabilitas secara tidak langsung melalui orientasi kewirausahaan tidak akan semakin meningkatkan inovasi. Dengan demikian $\mathrm{H}_{1.6}$ yang menyatakan "Adaptabilitas melalui mediasi orientasi kewirausahaan akan mampu meningkat-kan kinerja usaha” tidak dapat diterima.

\subsubsection{Pengujian Hipotesis 1.7}

Hasil pengujian statistik terhadap $\mathrm{H}_{1.7}$ menunjukkan bahwa adaptabilitas memiliki pengaruh langsung yang sangat signifikan terhadap inovasi dengan nilai estimasi baku sebesar 0,267 dan nilai probabilitas tingkat kesalahan 0,045. Demikian pula hasil pengujian $H_{1.5}$. menemukan inovasi berpengaruh langsung, positip dan siginifikan terhadap kinerja usaha dengan nilai estimasi baku sebesar 0,101 dan nilai probabilitas tingkat kesalahan 0,523. Sebaliknya pada pengujian $\mathrm{H}_{1.3}$ ditemukan adaptabilitas tidak memiliki pengaruh yang signifikan terhadap kinerja usaha. Dengan demikian dapat dinyatakan bahwa inovasi memediasi secara penuh pengaruh adaptabilitas terhadap kinerja usaha. Hasil ini memberi makna bahwa semakin tinggi adaptabilitas secara tidak langsung melalui inovasi secara penuh akan semakin meningkatkan kinerja usaha. Dengan demikian $\mathrm{H}_{1.7}$ yang menyatakan" Adaptabilitas melalui mediasi inovasi akan mampu meningkatkan kinerja usaha" dapat diterima.

\subsubsection{Pengujian Hipotesis 2.1}

Hasil pengujian statistik terhadap hipotesis ini menunjukkan orientasi kewirausahaan memiliki pengaruh langsung, positif dan sangat signifikan terhadap inovasi dengan nilai estimasi baku sebesar 0,593 dan nilai probabilitas tingkat kesalahan $<0,001$. Dengan menggunakan tingkat signifikansi alpha 0,05 maka $\mathrm{H}_{\text {.2.1. }}$ yang menyatakan " semakin tinggi orientasi kewirausahaan, akan semakin tinggi inovasi" dapat diterima.

\subsubsection{Pengujian Hipotesis 2.2}

Hasil pengujian $\mathrm{H}_{2.1}$. menunjukkan bahwa orientasi kewirausahaan memiliki pengaruh yang sangat signifikan terhadap inovasi dengan nilai estimasi baku sebesar 0,267 dan nilai probabilitas tingkat kesalahan 0,045. Demikian pula hasil pengujian $\mathrm{H}_{1.5}$ menemukan inovasi berpengaruh langsung, positip dan siginifikan terhadap kinerja usaha dengan nilai estimasi baku sebesar 0,101 dan nilai probabilitas tingkat kesalahan 0,523. Sebaliknya pada pengujian hipotesis $\mathrm{H}_{1.5}$, orientasi kewirausahaan tidak memiliki pengaruh langsung yang signifikan terhadap kinerja usaha dengan nilai estimasi baku sebesar -0,111 dan nilai probabilitas tingkat kesalahan 0,576. Hasil analisis ini menunjukkan bahwa inovasi memediasi secara penuh pengaruh orientasi kewirausahaan terhadap kinerja usaha. Hasil ini memberi makna bahwa semakin tinggi orientasi kewirausahaan secara tidak langsung melalui inovasi secara penuh akan semakin meningkatkan kinerja usaha. Dengan demikian $\mathrm{H}_{2.2}$. yang menyatakan "Orientasi kewirausahaan melalui mediasi inovasi akan mampu meningkatkan kinerja usaha." dapat diterima.

\section{Pembahasan Hasil Penelitian}

\subsection{Pembahasan Hipotesis 1.1.}

Hasil penelitian menunjukkan bahwa adaptabilitas sebagai budaya organisasi dan sebagai salah satu sumber keunggulan bersaing (Barney, 1986) memiliki peranan yang positif dalam 
meningkatkan orientasi kewirausahaan dimana semakin tinggi adaptabilitas, semakin tinggi orientasi kewirausahaan. Hasil ini sesuai dengan fenemona yang terjadi dilapangan, dari Indikator-Indikator yang digunakan untuk mengukur adaptabilitas menunjukkan hasil yang rendah. Dilihat dari rendahnya indikator kemampuan untuk menciptakan perubahan dan pembelajaran organisasi menunjukkan pada usaha-usaha mikro kerajinan rotan kurang terdapat nilai-nilai budaya adaptif yang dapat meningkatkan orientasi kewirausahaan, misalnya menjadi lebih proaktif dan inovatif.

Hasil ini memperluas penelitian empiris sebelumnya yang menemukan hubungan signifikan dan positif antara budaya organisasi dan beberapa indikator orientasi kewirausahaan seperti pengambilan resiko (Burgelman \& Sayles, 1986), keproaktifan (Miller \& Friesen, 1984), dan keinovasian (Kanter, 1982). Hasil penelitian ini juga sejalan dengan pendapat Zahra, et al. (1999) yang menyatakan salah satu faktor penting yang secara potensial dapat mempengaruhi arah, asal, dan pengaruh kegiatan kewirausahaan adalah budaya organisasi. Sedangkan Cornwall \& Perlman (1990) menyatakan bahwa budaya organisasi adalah kunci determinan dari orientasi kewirausahaan.

\subsection{Pembahasan Hipotesis 1.2}

Hasil penelitian menunjukkan adaptabilitas memiliki peranan yang positif dalam meningkatkan inovasi pada usaha mikro, dimana semakin tinggi adaptabilitas, semakin tinggi inovasi. Hasil ini sesuai dengan fenemona yang terjadi dilapangan, dari IndikatorIndikator yang digunakan untuk mengukur adaptabilitas menunjukkan hasil yang rendah. Dilihat dari rendahnya indikator kemampuan untuk menciptakan perubahan, pembelajaran organisasi dan focus pelanggan menunjukkan pada usaha-usaha mikro kerajinan rotan kurang terdapat nilai-nilai budaya adaptif yang dapat meningkatkan inovasi baik inovasi proses maupun produk.

Hasil penelitian memperluas hasil penelitian yang dilakukan oleh Lau \& Ngo (2004). Lau \& Ngo (2004) menunjukkan bahwa budaya-budaya organisasi dengan fleksibilitas dan adaptabilitas memiliki dampak positif terhadap inovasi organisasi. Daft (2007) mengusulkan bahwa budaya adaptabilitas ditandai dengan respon aktif untuk lingkungan yang dinamis melalui fleksibilitas dan perubahan. Melalui fleksibilitas dan responsif, organisasi dapat dengan cepat bereaksi terhadap lingkungan eksternal (Daft, 2007). Jenis budaya adaptabilitas memungkinkan organisasi untuk secara aktif merespon lingkungan eksternal dan akibatnya berkontribusi pada inovasi organisasi.

\subsection{Pembahasan Hipotesis 1.3}

Hasil penelitian menunjukkan adaptabilitas tidak memiliki peranan yang positif dalam meningkatkan kinerja usaha dimana semakin tinggi adaptabilitas tidak akan menyebabkan peningkatan kinerja usaha. Hal ini membuktikan bahwa belum dapat disimpulkan adanya pengaruh langsung dari adaptabilitas terhadap kinerja usaha sebagaimana pada penelitian Denison \& Mishra (1995), Denison et al. (2003), Fey \& Denison (2003), dan Yilmaz \& Ercan (2008) yang menyimpulkan adaptabilitas memiliki pengaruh positif terhadap kinerja usaha. Perbedaan utama dengan penelitian Denison \& Mishra (1995), Denison et al. (2003), Fey \& Denison (2003), dan Yilmaz \& Ercan (2008) terletak pada perbedaan obyek penelitian, dimana obyek penelitian merkea kebanyakan merupakan perusahaan manufaktur besar, sedangkan penelitian disertasi ini pada skala mikro.

Hasil penelitian ini menolak sepenuhnya hasil penelitian Ngo \& Loi (2008) yang mengeksplorasi hubungan antara fleksibilitas sumber daya manusia (SDM), budaya adaptabilitas, dan kinerja organisasi. Namun demikian, terdapat perbedaan yang berarti 
antara penelitian disertasi ini dengan penelitian Ngo \& Loi terutama berkaitan dengan obyek penelitian dan pengukuran variabel. Obyek penelitian Ngo \& Loi adalah Perusahaan multinasional yang beroperasi di Hongkong di awal tahun 2006 berjumlah sebanyak 181 buah. Sedangkan adaptablitas hanya diukur dengan tiga item pernyataan.

\subsection{Pembahasan Hipotesis 1.4.}

Hasil penelitian menunjukkan orientasi kewirausahaan tidak memiliki peranan yang positif dalam meningkatkan kinerja usaha dimana semakin tinggi orientasi kewirausahaan, secara langsung tidak akan mampu untuk meningkatkan kinerja usaha. Bahkan terdapat kecenderungan peranannya adalah negatif, meski tidak signifikan, peningkatan orientasi kewirausahaan cenderung dapat berakibat pada penurunan kinerja usaha. Hal ini dimungkinkan, karena kegiatan kewirausahaan umumnya membutuhkan sumberdaya yang lebih banyak dibanding organisasi yang konservatif (Chadwick et al., 2004). Usaha untuk mencari peluang guna mendapatkan kegiatan baru dan pengembangan produk baru umumnya memerlukan biaya dan waktu tanpa adanya jaminan peningkatan pada kinerja usaha, sehingga bila hal ini tidak dikelola dengan baik bisa berakibat pada penurunan kinerja usaha mereka.

Penemuan hasil empirik pengujian hipótesis penelitian ini menolak hasil penelitian Becherer (1997), Wiklund (1999), Deshpande (1999), Barringer \& Bluedorn (1999), Lumpkin \& Dess (2001); Wiklund \& Shepherd (2003), Zahra \& Covin (1995) dan Vitale et al. (2002) yang menemukan adanya pengaruh positif dari orientasi kewirausahaan terhadap Kinerja. Peneliti lain, yaitu Ferreira \& Azevedo (2007) yang mengkaji dampak orientasi kewirausahaan sebagai sumber daya dan kapabilitas utama menemukan pengaruh positif terhadap pertumbuhan perusahaan kecil.

Hasil penelitian ini sebaliknya memperluas hasil penelitian Auger et al. (2003) dan Smart \& Conant (1994), yang tidak dapat menemukan hubungan yang signifikan antara orientasi kewirausahaan dan kinerja. Hasil penelitian ini juga memperluas penelitian yang dilakukan oleh Chadwick et al. (2004) yang mengkaji secara empiris pengaruh orientasi kewirausahaan terhadap kinerja perusahaan di industri perbankan, yang menemukan tidak ada pengaruh yang signifikan antara orientasi kewirausahaan dan kinerja perbankan.

\subsection{Pembahasan Hipotesis 1.5 .}

Inovasi merupakan fungsi yang penting dalam manajemen, karena inovasi berhubungan dengan kinerja usaha, hal ini telah dibuktikan oleh (Damanpour \& Evan, 1984; Damanpour et al., 1988). Hasil temuan penelitian menunjukkan inovasi memiliki peranan yang positif dalam meningkatkan kinerja usaha dimana semakin tinggi inovasi, semakin tinggi kinerja usaha.

Hasil penelitian ini memperluas penelitian Rofiati (2010) tentang pengaruh kondisi lingkungan, perilaku berbagi pengetahuan, dan proses perencanan strategis terhadap inovasi dan kinerja pada UKM sentra kerajinan Kulit di Jawa Timur). Dengan jumlah sampel sebanyak 184 UKM, hasil penelitiannya menunjukkan inovasi yang dilakukan UKM terbukti mampu meningkatkan kinerja bisnis.

\subsection{Pembahasan Hipotesis 1.6.}

Hasil penelitian menemukan orientasi kewirausahaan tidak berperan sebagai variabel mediasi pengaruh adaptabilitas terhadap kinerja usaha. Sebelumnya diketahui bahwa adaptabilitas secara langsung tidak memiliki peranan positif dalam meningkatkan kinerja usaha, jadi meskipun dalam hubungan ini ditambahkan orientasi kewirausahaan sebagai 
mediator, adaptabilitas secara tidak langsung juga tidak akan memiliki peranan yang positif dalam meningkatkan kinerja usaha. Hal ini dikarenakan orientasi kewirausahaan tidak memiliki peranan yang signifikan terhadap kinerja usaha sehingga peranan mediasi dari orientasi kewirausahaan pada pengaruh adaptabilitas terhadap kinerja usaha tidak terdapat.

Hasil penelitian ini menunjukkan bahwa meskipun pada usaha mikro kerajinan rotan memiliki kemampuan dalam menciptakan perubahan yang adaptif dan pembelajaran organisasional yang tergolong moderate bigh dan diketahui memiliki peranan yang positif terhadap orientasi kewirausahaan, namun tidak memiliki peranan yang positif baik langsung maupun tidak langsung terhadap kinerja usaha melalui orientasi kewirausahaan. Hal ini dikarenakan kemampuan dalam menciptakan perubahan yang adaptif dan pembelajaran organisasional terfokus hanya pada pengelola/pemilik usaha mikro saja, selain itu pembelajaran organisasi yang ada tidak fokus pada aspek teknis produksi dalam mencapai peningkatan kinerja usaha, melainkan masih bersifat norma-norma saja.

\subsection{Pembahasan Hipotesis 1.7}

Hasil penelitian menunjukkan inovasi secara penuh berperan sebagai variabel mediasi pengaruh adaptabilitas terhadap kinerja usaha. Dengan perkataan lain adaptabilitas secara langsung tidak memiliki peranan yang positif dalam meningkatkan kinerja usaha. Namun, jika dalam hubungan ini ditambahkan inovasi sebagai mediator, adaptabilitas secara tidak langsung akan memiliki peranan yang positif dalam meningkatkan kinerja usaha.

Hasil temuan penelitian ini dapat menjelaskan mengapa beberapa perusahaan yang memiliki tingkat adaptabilitas yang tinggi memiliki kinerja usaha yang rendah, hal ini dikarenakan boleh jadi inovasi yang menjadi diterminan dari kinerja usaha tidak terdapat dalam hubungan ini. Dengan perkataan lain meskipun perusahaan tersebut mampu menciptakan berbagai perubahan seiring dengan perubahan lingkungan dan selalu melakukan kegiatan pembelajaran organisasi, namun apabila usaha tersebut tidak mampu untuk menciptakan inovasi (produk dan atau proses), maka penciptaan perubahan dan pembelajaran organisasi tersebut tidak memberikan peranan yang positif terhadap kinerja usaha.

\subsection{Pembahasan Hipotesis 2.1}

Hasil penelitian menunjukkan orientasi kewirausahaan memiliki peranan yang positif dalam meningkatkan inovasi dimana semakin tinggi orientasi kewirausahaan, semakin tinggi inovasi pada usaha mikro. Hasil ini sesuai dengan fenemona yang terjadi dilapangan, dari Indikator- Indikator yang digunakan untuk mengukur orientasi kewirausahaan menunjukkan hasil yang rendah. Dilihat dari indikator keinovasian dan pengambilan resiko yang rendah menunjukkan usaha-usaha mikro kerajinan rotan kurang memberikan perhatian pada kemauan untuk berinovasi dalam meningkatkan inovasi maupun keranian mengambil resiko dalam mengembangkan produk baru. Hasil penelitian ini memperluas hasil penelitian Avlonitis \& Salavou (2007), dan Atuahene-Gima \& Ko (2001) yang menyimpulkan bahwa orientasi kewirausahaan berpengaruh positif terhadap inovasi. Menurut Hurley et al. (2003), orientasi kewirausahaan merupakan salah satu pendorong yang sangat penting terhadap inovasi.

\subsection{Pembahasan Hipotesis 2.2}

Hasil penelitian menunjukkan inovasi secara penuh berperan sebagai variabel mediasi pengaruh orientasi kewirausahaan terhadap kinerja usaha. Temuan hasil penelitian ini menunjukkan bahwa orientasi kewirausahaan mempengaruhi kinerja usaha secara tidak langsung. Hasil penelitian ini memperluas hasil penelitian Alegre \& Chiva (2009) yang meneliti hubungan antara orientasi kewirausahaan, kapabilitas pembelajaran organisasi, 
inovasi dan kinerja perusahaan. Sampel penelitian adalah 82 perusahaan Italia dan 100 perusahaan Spanyol yang bergerak di bidang industri tegel keramik. Salah satu hasil penelitian mereka menyimpulkan bahwa inovasi memediasi pengaruh orientasi kewirausahaan terhadap kinerja perusahaan

Hasil temuan penelitian ini dapat menjelaskan mengapa beberapa perusahaan menunjukkan kinerja yang rendah padahal perusahaan tersebut menunjukkan orientasi kewirausahaan yang tinggi, hal ini dikarenakan boleh jadi inovasi yang menjadi determinan dari kinerja usaha tidak terdapat dalam hubungan ini (missing link). Dengan perkataan lain meskipun perusahaan tersebut memiliki tingkat orientasi kewirausahaan yang tinggi melalui kegiatan kewirasuahaan, namun apabila perusaha tersebut tidak mampu untuk menciptakan inovasi, maka orientasi kewirausahaan yang tinggi tersebut tidak memberikan peranan yang positif terhadap kinerja usaha.

\section{Model Hasil Penelitian}

Hasil uji fit model menunjukkan model empirik penelitian memenuhi kriteria goodness of fit. Dengan demikian, adaptabilitas, orientasi kewirausahaan dan inovasi secara keseluruhan memiliki peranan positif baik langsung maupun tidak langsung terhadap kinerja usaha. Model hasil penelitian empirik peranan adaptabilitas, orientasi kewirausahaan dan inovasi terhadap kinerja pada usaha mikro kerajinan rotan diperlihatkan pada Gambar 2.

Gambar 2. Model hasil penelitian empirik peranan adaptabilitas, orientasi kewirausahaan dan inovasi terhadap kinerja pada usaha mikro kerajinan rotan

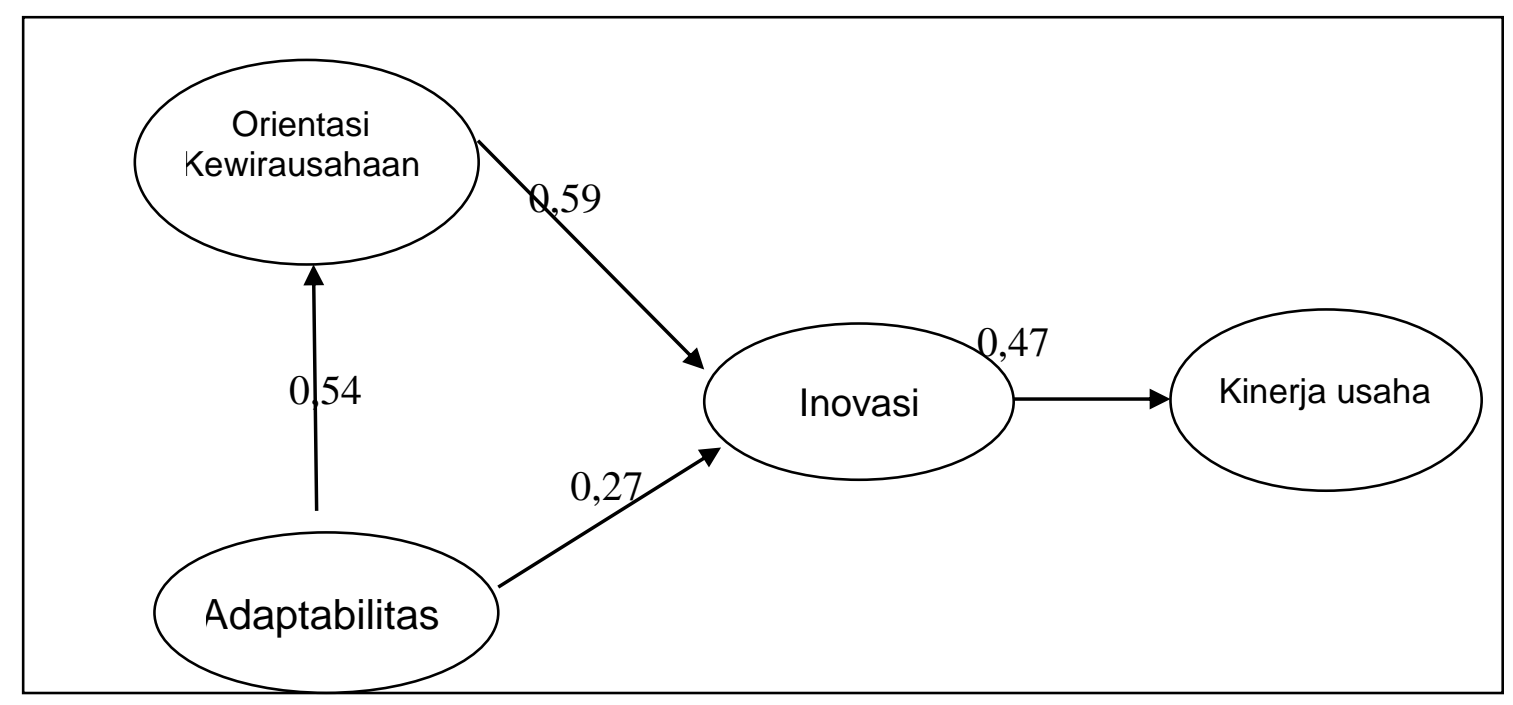

Berdasarkan pada Gambar 2. terlihat bahwa adaptabilitas memiliki peranan positif dalam meningkatkan orientasi kewirausahaan dan inovasi, kemudian orientasi kewirausahaan memiliki peranan positif dalam meningkatkan inovasi, dan selanjutnya inovasi memiliki peranan positif dalam meningkatkan kinerja usaha. inovasi merupakan determinan terpenting dalam proses peningkatan kinerja usaha dengan koefesien jalur 0,47 Sedangkan terciptanya inovasi ditentukan oleh peranan orientasi kewirausahaan dengan koefesien jalur 0,59 dan peranan adaptabilitas dengan koefesien jalur 0,27 peningkatan orientasi kewirausahaan sangat ditentukan oleh adaptabilitas dengan koefesien jalur 0,54. 
Hasil penelitian ini menunjukkan bahwa terdapat dua cara untuk meningkatkan kinerja usaha. Pertama, dengan cara meningkatkan inovasi, cara ini dapat diterapkan terutama pada usaha mikro kerajinan rotan yang telah memiliki kemampuan adaptasi dan orientasi kewirausahaan yang tinggi. Sedangkan kedua adalah dengan cara terlebih dahulu meningkatkan orientasi kewirausahaan sebelum meningkatkan inovasi.

\section{Implikasi Penelitian}

\subsection{Implikasi Teoritis}

Model yang diuji dalam penelitian ini, didasarkan dan dikembangkan dari berbagai kajian teori dan kajian empirik. Oleh karenanya, hasil penelitian ini diharapkan dapat memberi dampak implikasi pada berbagai teori yang mendasarinya terutama teori Resource Based View. Adapun teori budaya organisasi, teori orientasi kewirausahaan dan teori inovasi merupakan konsep teori yang mengacu pada teori Resource Based View dimana kunci keberhasilan perusahaan berasal dari karakteristik sumberdaya dalam suatu perusahaan itu sendiri.

Pertama, berdasarkan sudut pandang RBV, hasil penelitian ini membuktikan bahwa peningkatan inovasi tidak hanya berasal dari hasil pemindaian lingkungan eksternal untuk peluang pasar, namun juga dapat dikembangkan dengan memperhatikan aspek budaya organisasi yang berorientasi eksternal (adaptabilitas) dan orientasi kewirausahaan. Kedua, hasil penelitian ini membuktikan bahwa adaptabilitas sebagai salah satu komponen budaya organisasi memiliki peranan yang positif dalam meningkatkan orientasi kewirausahaan, hal ini mendukung Model Kewirausahaan sebagai Firm Behavior (Covin \& Slevin, 1991) yang menunjukkan bahwa salah satu anteseden dari orientasi kewirausahaan adalah budaya organisasi.

Ketiga, penelitian ini membuktikan bahwasanya orientasi kewirausahaan ditemukan menjadi faktor penting dalam meningkatkan inovasi. Hasil penelitian ini memberikan kontribusi penting terhadap penelitian inovasi. Hasil penelitian memberikan bukti lebih lanjut yang mendukung untuk membuktikan peranan positif yang ditemukan pada penelitian sebelumnya yang berkaitan dengan inovasi dan kinerja usaha (Calantone et al., 2002; Hult et al., 2004; Prajogo, 2006; Keskin, 2006 dan Lin \& Chen, 2007) tentang pengaruh inovasi terhadap kinerja usaha. Selain itu, penelitian ini membuktikan pengaruh tidak langsung dari adaptabilitas dan orientasi kewirausahaan terhadap kinerja perusahaan melalui inovasi. Ini merupakan kontribusi tambahan dalam penelitian budaya organsiasi, orientasi kewirausahaan, inovasi dan kinerja usaha mikro. Keempat, dalam penelitian ini terbukti bahwa inovasi memediasi penuh pengaruh orientasi kewirausahaan terhadap kinerja usaha. Hasil ini memberikan kontribusi teoritis yang menegaskan bahwa hubungan antara orientasi kewirausahaan dan kinerja usaha tidaklah sederhana melainkan kompleks.

\subsection{Implikasi Manajerial}

Implikasi manajerial dalam penelitian ini diperoleh dari hasil analisis pengaruh antar variabel penelitian. Terdapat langkah-langkah utama yang dapat dilakukan pemilik /pengelola usaha mikro dalam rangka meningkatkan kinerja usahanya. Pertama adalah meningkatkan inovasi, hasil penelitian menunjukkan bahwa inovasi merupakan variabel yang penting dalam meningkatkan kinerja usaha mikro. Selain itu inovasi ternyata juga merupakan variabel mediasi penuh (Full mediation) pengaruh adaptabilitas terhadap kinerja usaha maupun pengaruh orientasi kewirausahaan terhadap kinerja usaha. Peningkatan inovasi dapat dilakukan dengan meningkatkan inovasi proses dan inovasi produk. Ini semua dapat dilakukan dengan mengikuti berbagai kegiatan pelatihan teknis yang diselenggarakan 
oleh berbagai pihak (Pemerintah, Swasta, LSM) berkaitan dengan usaha peningkatan kualitas dan desain produk yang selama ini masih merupakan kelemahan bagi usaha mikro dalam pengembangan produk baru.

Kedua adalah meningkatkan orientasi kewirausahaan. Karena orientasi kewirausahaan memiliki peranan yang sangat positif terhadap inovasi. Peningkatan orientasi kewirausahaan dilakukan dengan cara berupaya lebih proaktif dan lebih inovatif. Hal ini dapat dilakukan dengan lebih proaktif dalam mencari peluang-peluang guna mendapatkan pesanan dari pelanggan serta dapat meningkakan kreatifitas mengembangkan ide-ide baru dalam proses pengembangan produk baru. Para pengusaha mikro hendaknya dapat mencari peluang baru dengan mencari proyek-proyek pengadaaan barang dari pemerintah, serta dapat mencari informasi mengenai selera konsumen di dalam maupun luar negeri. Ketiga adalah peningkatan adaptabilitas. Adaptabilitas diperlukan terutama untuk meningkatkan orientasi kewirausahaan. Peningkatan adaptabilitas dilakukan dengan cara berupaya menciptakan perubahan yang produktif dan meningkatkan pembelajaran organisasi. Pembelajaran organisasi dapat dilakukan baik secara formal maupun non formal.

Temuan penelitian ini memberikan sumbangan pemikiran bagi pemerintah daerah pada kebijakan untuk meningkatkan kinerja usaha mikro khususnya usaha kerajinan rotan di Kalimantan Selatan yakni pertama, pada usaha mikro yang mempunyai karakteristik sumberdaya dengan tingkat orientasi kewirausahaan yang tinggi, untuk meningkatkan kinerja usaha dapat dilakukan dengan usaha peningkatan inovasi. Sedangkan pada usaha mikro yang mempunyai karakteristik sumberdaya dengan tingkat orientasi kewirausahaan yang rendah, untuk meningkatkan kinerja usaha dapat dilakukan dengan meningkatkan adaptabilitas diiringi dengan peningkatan inovasi. Kegiatan-kegiatan pemberdayaan dan pembinaan usaha mikro kecil perlu dijalankan secara terus menerus untuk meningkatkan adaptabilitas, orientasi kewirausahaan dan inovasi usaha mikro. Kedua, pemerintah diharapkan selain dapat meningkatkan kemampuan teknis juga diharapkan dapat memberikan bantuan permodalan mengingat kebanyakan pengusaha mikro masih mengalami kesulitan dalam memperoleh permodalan karena persyaratan agunan yang diminta oleh kreditor (perbankan).

\section{Simpulan}

Berdasarkan uraian di atas dapat disimpulkan hasil penelitian sebagai berikut: pertama, ada usaha mikro kerajinan rotan, adaptabilitas sebagai sumberdaya tak berwujud memiliki peranan positif dalam meningkatkan orientasi kewirausahaan dan inovasi secara langsung, tetapi tidak memiliki peranan positif terhadap kinerja usaha secara langsung. Adaptabilitas hanya memiliki peranan positif secara tidak langsung melalui inovasi. Kedua, pada usaha mikro industri kerajinan rotan, orientasi kewirausahaan sebagai sumberdaya tak berwujud memiliki peranan positif dalam meningkatkan inovasi. Orientasi kewirausahaan melalui mediasi inovasi akan mampu meningkatkan kinerja usaha mikro kerajinan rotan. Ketiga, penelitian ini menghasilkan model penelitian yang dapat dijadikan untuk memahami bagaimana cara meningkatkan kinerja usaha mikro kerajinan di Kalimantan Selatan. Inovasi yang tinggi diperlukan untuk meningkatkan kinerja usaha, sedangkan orientasi kewirausahaan yang tinggi untuk meningkatkan inovasi dan adaptabilitas yang diperlukan untuk meningkatkan orientasi kewirausahaan. Inovasi dalam penelitian ini merupakan temuan terpenting dikarenakan memiliki peranan positif secara langsung terhadap kinerja usaha. Selain itu inovasi merupakan mediasi yang menghubungkan adaptabilitas dan 
orientasi kewirausahaan dengan kinerja usaha. Temuan penting berikutnya adalah adaptabilitas, yang meskipun tidak memiliki peranan positif secara langsung terhadap kinerja usaha, namun memiliki peranan positif terhadap orientasi kewirausahaan dan inovasi.

\section{Daftar Pustaka}

Bailey, J. "Learning Styles of Successful Entrepreneurs." In Frontiers of Entrepreneurship Research. Wellesley: Babson College Press, 1986.

Barney, J. B. "Firm Resources and Sustained Competitive Advantage." Journal of Management 17 (1991).

Capon S. N., J.U Farley, and Hoening. "Determinants Of Financial Performance: A MetaAnalysis." Management Science 36, no. 10 (1990).

Cooper, A.C. "R\&D Is More Efficient in Small Companies?" Harvard Business Review, 3, 42 (1964).

Covin, J.G., and M.P. Miles. "Corporate Entrepreneurship And The Pursuit Of Competitive Advantage." Entrepreneurship Theory and Practice 23 (1999).

Covin, and Slevin. "A Conceptual Model Of Entrepreneurship As Firm Behavior." Entrepreneurship Theory and Practice 16 (1991).

D, A. O’Donnell, Gilmore, A., Carson, D., \& Cummins,. "Competitive Advantage in Small to Medium-Sized Enterprises.” Journal of Strategic Marketing, 3, 10 (2002).

Damanpour, F. "Organizational Complexity And Innovation: Developing And Testing Multiple Contingency Models." Management of Science, 2, 45 (1996).

Ferreira, J., and S.G. Azevedo. "Entrepreneurial Orientation (EO) And Growth Of Firms: Key Lessons For Managers And Business Professionals." Problems And Perspectives In Management, 6, no. 1 (2008).

Freel, M.S. "Barriers to Product Innovation in Small Manufacturing Firms." International Small Business Journal, 2, 18 (2000).

"Human Resource Management: A Survey of Practices WithinFfamily and Non-Family Firms." Journal of European Industrial Training, 6, 25 (2001).

Ireland, R. D., and J. W. Webb. "A Cross-Disciplinary Exploration of Entrepreneurship Research." Journal of Management, 6, 33 (2007).

J. Loan-Clarke, Boocock, G., Smith, A. and Whittaker, J. "Investment in Management Training and Development by Small Businesses.” Employee Relations, 3, 21 (1999).

Joaquín Alegre, and Chiva Ricardo. Entrepreneurial Orientation, Innovation Firm Performance: The Importance of Organizational Learning Capability, n.d.

Liputan6.com. "UMKM Sumbang 60 Persen ke Pertumbuhan Ekonomi Nasional." liputan6.com, July $\quad 6, \quad 2018$. https://www.liputan6.com/bisnis/read/3581067/umkm-sumbang-60-persen-kepertumbuhan-ekonomi-nasional.

Lumpkin, G.T., and G.G. Dess. "Clarifying The Entrepreneurial Orientation Construct And Linking It To Performance,." Academy of Management Review 21 (n.d.). 
M, J. Philipson. "Adaptive Responses and Asset Strategies; the Experience of Rural MicroFirms and Foot and Mouth Disease." Journal of Rural Studies 20 (2004).

Prajogo, Daniel I. "The Relationship between Innovation and Business Performance-A Comparative Study between Manufacturing and Service Firms." Knowledge and Process Management, 3, 13 (2006).

Rothwell, R. Industrial Innovation: Success, Strategy, Trends. The Handbook of Industrial Innovation, 1994.

Roy, P. "The Hewlett Packard-Compaq Computers Merger: Insight from the ResourceBased View and Dynamic Capabilities Perspective." The Journal of American Academy of Business, September 2004.

Runyan, R. C., P. Huddleston, and J. Swinney. "Entrepreneurial Orientation And Social Capital As Small Firm Strategies: A Study Of Gender Differences From A Resource-Based View.” Entrepreneurship Mgt 2 (2006).

Semeru. "Laporan Lapangan Keberadaan Upaya Penguatan Usaha Mikro Di Enam Kabupaten/Kota." Http://Www.Semeru.or.Id/Report/ Field/Usabamikro2/, 2003, Buku II edition.

Vossen, R. "Relative Strengths and Weakness of Small Firms in Innovation." International Small Business Journal, 3, 16 (1998).

Wicklund, J. "The Sustainability Of The Entrepreneurial Orientation-Performance Relationship." Entrepreneurship Theory and Practice 24 (1999).

Zahra, S.A., D. O. Neubaum, and M. Huse. "Entrepreneurship In Medium-Size Companies: Exploring The Effects Of Ownership And Governance Systems." Journal of Management, 5, 26 (2000). 